\title{
THE CATEGORY OF MEDIA TEXT CONVERSE AS A REFLECTION OF THE AUTHOR'S IDIOSTYLE
}

\author{
Nina S. Bolotnova \\ Tomsk State Pedagogical University, Tomsk, Russia
}

\begin{abstract}
Dynamically altering reality stimulates the use of new means and ways of communication in the process of textual activity. Peculiarities of present-day media communication (polycode, polydiscursiveness, intertextuality, interactivity, openness, etc.) and anthropocentrism of the modern linguistic paradigm determine the dialogue between the author and the addressee based on the text, which requires special study. The identification of the means and ways of expressing the category of media text dialogicity in the aspect of idiostyle is carried out on the basis of the analysis of the texts regulativity in the context of the communicative-activity approach to it. A broad range of linguistic and extralinguistic means of dialogization, which are typical of the author's journalistic texts, was revealed in the mainstream of the theory of regulation as one of the directions of communicative stylistics, based on the articles of 2020 in the "Rossiyskaya Gazeta" by the famous journalist and political scientist L. Radzikhovsky. The sphere of communication, the author's idiostyle, the peculiarities of the representation of regulation as a systemic quality of the media text are considered as factors that influence the dialogue with the addressee. The approach to the analysis of the media text based on the allocation of various regulatory means, structures, methods of regulation, and regulatory strategy that controls the cognitive activity of the addressee allows us to judge upon the specificity of the dialogic character of the modern publicistic text in accordance with the genre of the article in the aspect of the author's idiostyle. The proposed approach also is of interest for media linguistics and mediastylistics, the communicative theory of text, theory of speech impact.
\end{abstract}

Key words: category of dialogicity, media text, communicative stylistics, theory of regulation, idiostyle.

Citation. Bolotnova N.S. The Category of Media Text Converse as a Reflection of the Author's Idiostyle. Vestnik Volgogradskogo gosudarstvennogo universiteta. Seriya 2. Yazykoznanie [Science Journal of Volgograd State University. Linguistics], 2021, vol. 20, no. 2, pp. 16-25. (in Russian). DOI: https://doi.org/10.15688/ jvolsu2.2021.2.2

УДК 81’42:070

Дата поступления статьи: 12.11.2020

ББК 81.055 .1 Дата принятия статьи: 12.01.2021

\section{КАТЕГОРИЯ ДИАЛОГИЧНОСТИ МЕДИАТЕКСТА КАК ОТРАЖЕНИЕ ИДИОСТИЛЯ АВТОРА}

\author{
Нина Сергеевна Болотнова \\ Томский государственный педагогический университет, г. Томск, Россия
}

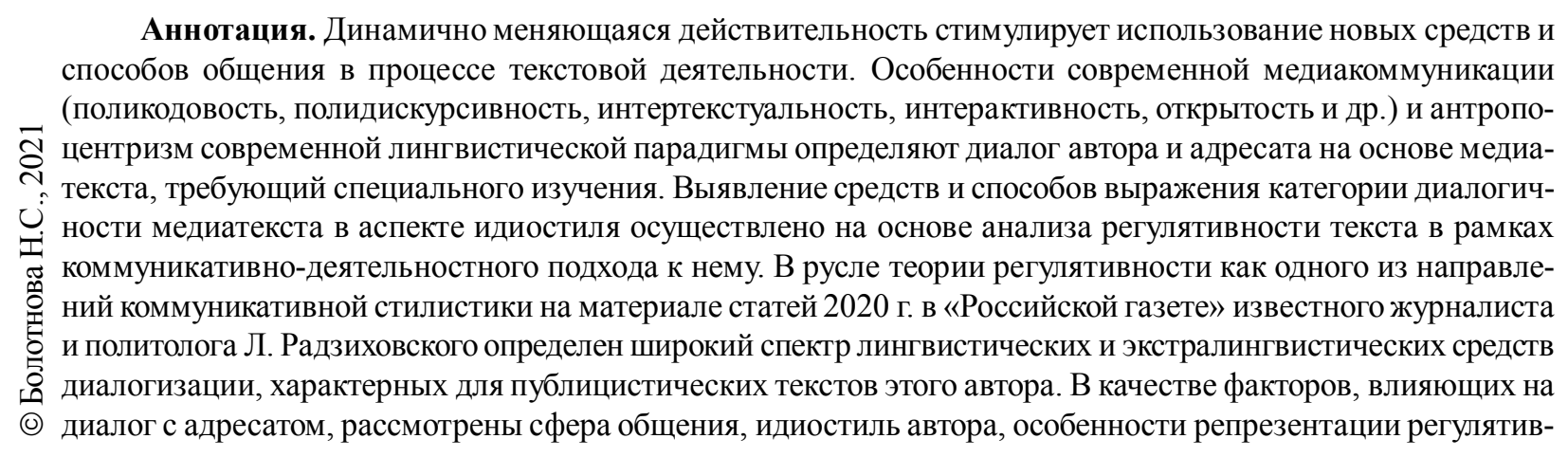


ности как системного качества текста. Предложенный подход к анализу медиатекста на основе выделения управляющих познавательной деятельностью адресата различных регулятивных средств, структур, способов регулятивности, регулятивной стратегии позволяет судить о специфике диалогичности современного публицистического текста в жанре статьи в аспекте идиостиля автора и представляет интерес для медиалингвистики и медиастилистики, коммуникативной теории текста, теории речевого воздействия.

Ключевые слова: категория диалогичности, медиатекст, коммуникативная стилистика, теория регулятивности, идиостиль.

Цитирование. Болотнова Н. С. Категория диалогичности медиатекста как отражение идиостиля автора // Вестник Волгоградского государственного университета. Серия 2, Языкознание. - 2021. - Т. 20, № 2. - С. 1625. - DOI: https://doi.org/10.15688/jvolsu2.2021.2.2

\section{Введение}

Новые информационные технологии и изменения в жизни современного общества с учетом динамики современного мира стимулируют особый интерес к медиатекстам (см. работы Т.Г. Добросклонской, И.В. Анненковой, Л.Р. Дускаевой, М.Ю. Казак, Н.И. Клушиной, Т.В. Чернышевой и др.). Поскольку в медиалингвистике термин «медиатекст» используется «в качестве родового по отношению к серии традиционных и новых обозначений: публицистический текст, газетный текст, радио- и телетекст, сетевой текст, гипертекст, рекламный текст и т. п.» [Казак, 2014, с. 65], далее данный термин используется в статье наряду с термином «газетно-публицистический текст». Так как любой текст ориентирован на адресата, выявление специфики средств выражения категории диалогичности в разных сферах общения, особенно в современных массмедиа, актуально.

Изучение текстовой категории диалогичности имеет давнюю историю, связанную с именем М.М. Бахтина, который писал: «Событие жизни текста, то есть его подлинная сущность, всегда развивается на рубеже двух сознаний, двух субъектов» [Бахтин, 1997, c. 229]. Как «фундаментальное свойство речи вообще», как «всеобщий ее признак, выступающий как речевая реализация коммуникативной функции языка» рассматривала диалогичность М.Н. Кожина [Кожина, 1986, с. 37]. Новая лингвистическая парадигма, отражающая коммуникативно-деятельностный подход к тексту, стимулировала особое внимание к текстовой деятельности и развитие новых направлений исследования, включая коммуникативную стилистику. В ее задачи входит изучение различных средств и способов органи- зации диалога автора и адресата текста, выявление различных закономерностей процесса коммуникации, осуществляемой на основе текстовой деятельности с учетом экстралингвистических факторов [Болотнова, 2009; Коммуникативная стилистика..., 2011; Языковая личность..., 2017].

Разработанная в рамках коммуникативной стилистики теория регулятивности учитывает достижения лингвистической прагматики [Барт, 2001; Болотнова, 2008; Дейк, 2001; Коммуникативная стилистика..., 2011], коммуникативной лингвистики [Демьянков, 1983; Каменская, 1990; Сидоров, 1987], теории дискурса [Арутюнова, 1990; Гаспаров, 1996; Дейк, 1989; Карасик, 2004; и др.]. Вслед за Е.В. Сидоровым регулятивность рассматривается как системное качество текста, связанное с его информативностью, структурностью, интегративностью [Сидоров, 1987].

В рамках концепции регулятивности нами выделены различные типы регулятивных средств на уровне элементов текста, связанные с осознаваемыми адресатом микроцелями автора; регулятивные структуры (стилистические приемы, текстовые парадигмы, типы выдвижения); способы регулятивности (принципы организации текста); регулятивные стратегии, отражающие поэтапное приобщение адресата к коммуникативной стратегии автора [Болотнова, 1998; Болотнова, 2009]).

Текстовая категория диалогичности рассматривается в коммуникативной стилистике как ключевая. В рамках этой категории выделяются субкатегории субъектности и адресованности, связанные с образами автора и адресата. Применительно к медиатексту субкатегория субъектности реализуется на уровне автор - реальное лицо и образ автора как глобальная категория, которая синтезирует 


\section{ТЕОРЕТИЧЕСКИЕ ПРОБЛЕМЫ ИССЛЕДОВАНИЯ ТЕКСТОВ}

структуру, семантику и прагматику текста и отражает особенности реального автора, «стоящего» за текстом. Его идиостиль трактуется как «индивидуально-авторские особенности мировидения и текстовой деятельности, отраженные в тексте как форме коммуникации, включая организацию диалога с читателем» [Болотнова, 2018, с. 201]. Субкатегория адресованности связана с реальным адресатом текста (читателем, слушателем) и с собирательным образом адресата как текстообразующей категорией.

В условиях медикоммуникации адресат часто становится автором вторичного или третичного текста (термин А.В. Болотнова), отражающих реакции на первичный или вторичный текст. В итоге рождаются «информационное эхо» и информационные волны разных типов, выделенные и описанные А.В. Болотновым [Болотнов, 2015; Языковая личность..., 2017]. О вторичных текстах и характерной для них функционально-семантической категории аппроксимации, «обозначающей реализацию значения приблизительности, неточности средствами языка и текста», писала С.В. Ионова [Ионова, 2005; 2006].

Целью данной статьи является рассмотрение категории диалогичности первичного медиатекста на материале статей яркого журналиста и политолога Леонида Радзиховского, имеющего свой индивидуальный стиль, который отражается в использовании различных регулятивных средств и структур, отражающих категорию диалогичности.

\section{Методика исследования}

Категория диалогичности рассматривается в статье с учетом специфики медиатекстов на основе разработанной в коммуникативной стилистике методики анализа их регулятивности. Данная методика включает: выделение регулятивных средств разных типов; их рассмотрение в рамках регулятивных структур; определение способа регулятивности и регулятивной стратегии текста; обобщение полученных наблюдений и конкретизацию глубинного смысла текста и интенции автора. Общее направление такого исследования связано с переходом от анализа текста в дискурс: по мнению Т.А. ван Дейка, дискурс «в широком смысле слова является сложным единством языковой формы, значения и действия, которое могло бы быть наилучшим образом охарактеризовано с помощью понятия коммуникативного события или коммуникативного акта» [Дейк, 1989, с. 121]. Регулятивность как системное качество текста отражает его смысловое развертывание в соответствии с интенцией автора и стимулирует потенциальную познавательную деятельность адресата, то есть определяет диалог автора с ним через текст как объект восприятия и интерпретации.

\section{Результаты и обсуждение}

Взятый для анализа материал позволяет выделить различные регулятивные средства и способы организации диалога с коллективным адресатом, свойственные тексту статьи, «в котором на первый план выходит лингвистическая демонстрация причинно-следственных связей между суждениями» [Дускаева, 2018, c. 182]. При этом надо учитывать сферу общения и функционально-стилистическую маркированность текста. К особенностям текстов публицистического стиля Г.Я. Солганик отнес социальную оценочность, специфику автора, который является конкретной личностью («частным человеком») и «человеком социальным», документальность, эмоциональность, субъективность [Солганик, 2003, c. 313-314].

На уровне общих тенденций для современных медиатекстов характерны яркие регулятивные средства с четко акцентированной целевой установкой, регулятивные структуры эксплицитного типа (повтор, контраст, обманутое ожидание, конвергенция), сильные регулятивные стратегии, основанные на контрастах и парадоксах текстового развертывания, а также стратегии последовательно-конвергентного типа, связанные с поэтапным усилением разными средствами доминантных смыслов, отражающих интенции авторов [Болотнова, 2019, с. 49].

Для анализа категории диалогичности медиатекста, рассматриваемой в идиостилевом аспекте, обратимся к эмпирическому материалу. Проблемно-аналитическая статья «Величие Америки» в «Российской 
газете» (Радзиховский, 2020а) посвящена размышлениям журналиста и политолога Л. Радзиховского о месте США в мире накануне выборов президента. Автора медиатекста отличает высокая риторическая культура, умелое использование риторических приемов, различных регулятивных средств и структур, отражающих категорию диалогичности. Основные способы регулятивности (принципы текстовой организации) в статье - конвергенция и контраст. Поверхностный смысл данного медиатекста - актуализация идеи величия Америки в прошлом и настоящем. Глубинный смысл сложность достижения и сохранения величия страны в условиях меняющегося мироустройства.

Анализируемый медиатекст имеет регулятивную лексическую макроструктуру эксплицитного дедуктивного типа, отражающую в экспрессивной речевой манере общую логику рассуждений журналиста, включая выделение тезиса и его доказательств, выдвижение аргументов и выводов на их основе. Благодаря этому потенциальный адресат приобщается к интенции автора, вступает с ним в диалог, что достигается использованием особых регулятивных структур. Доминантными регулятивными структурами в статье являются:

- многочисленные риторические вопросы: Так, значит, величие куда-то ушло (уходит)? Куда, почему? И как же его вернуть?; Что есть Сила Страны?; Может быть, скоро Китай начнет задавать миру свои (какие?!) правила - хотя бы в экономике, торговле, финансах? Или вообще свой дискурс (опять - какой?). Или это нереально? и др.;

- антитеза, используемая многократно: Закат Европы стал «Рассветом Америки»; шумно или молча признается «лучшей» (о программе «Величия»); Китай - одна из немногих стран, где ВВП в 2020 г. растет, а не падает; Сила - не в Больших Батальонах, а в Экономике; Так Новый Свет шел впереди Старого Света;

- градация: Понятно, «закат» не означает «гибель». Звучит слишком пафосно, но это - объективная потребность («скрепа») многих государств, наиий, обществ, элит и более широких слоев.
Ярким средством выражения авторской оценки ключевого события (выборы президента США) в статье является текстовая парадигма номинатов. Элементы данной парадигмы характеризуются стилистической неоднородностью и усилены в тексте графическими средствами регулятивности: Мировое Шоу Года, финиш-катарсис, суетня. Графические регулятивные средства используются автором особенно часто. Например, главные в смысловом и прагматическом отношении слова выделяются в статье прописными буквами: СМЫСЛ; ПО-СВОЕМУ (жить); СВОЮ (программу); СИЛЬНЕЕ (богаче) ДРУГИХ (быть); ИЗБРАННОСТЬ; в ОЩУЩЕНИИ (дело) и др. Написание некоторых ключевых в плане воздействия слов с прописной буквы служит средством привлечения внимания адресата, акцентирования на логически значимых смысловых вехах в диалоге с ним: Исходная Вера в Особый Путь; Наука, Технологии, Информаџия; эра Мирового Монополизма США и др.

Для усиления аргументации журналист использует цифровые показатели как важное регулятивное средство, убеждая читателя в справедливости выдвинутого тезиса о меняющемся мироустройстве: $B$ 1990-м доля США в мировом ВВП - $22 \%$, КНР $4 \%$. В 2013-м Китай догнал США - по $16 \%$ у каждого и стал неумолимо обходить. «При Трампе» разрыв вырос с 2,1\% до $3,6 \%$.

Одним из средств выражения диалогизации в статье является использование прецедентных текстов, к которым, в частности, относятся: Вернем Америке былое величие (лозунг Д. Трампа); Все великое земное / Разлетается, как дым: / Ныне жребий выпал Tрое, / Завтра выпадет другим... (цитата из стихотворения В.А. Жуковского «Торжество победителей», перевод баллады Шиллера «Das Siegesfest», 1829).

Опора на широкий социально-исторический контекст делает эффектным и употребление различных эвфемизмов: диссидент (о России, входящей «в эту Сверх-Цивилизацию»), Мировое Шоу года (о выборах президента в США); задача, названная Трампом 4 года назад; Атлантический, Белохристианский (Западный мир); Тем време- 


\section{ТЕОРЕТИЧЕСКИЕ ПРОБЛЕМЫ ИССЛЕДОВАНИЯ ТЕКСТОВ}

нем в США - постановки «1984»; с «новоязом» («черное и белое» не говорите); мысслепреступлениями, 5-минутками ненависти; война нового типа - без выстрелов $и$ столкновений государств (о ситуации с ковидом). В целях воздействия на читателя умело употребляются различные эпитеты, среди которых есть метафорические: звонкий слоган, 3 Мировая ковидная; Но Вечных Чемпионов, как и Конияа Истории, - не бывает и др.

Показательно, что Л. Радзиховский для воздействия на массового адресата и усиления регулятивного эффекта применяет различные сочетания регулятивных средств и структур. Сравним нанизывание определений в сочетании с графическими средствами: $K$ 1990-м сложилась уникальная ситуаџия Абсолютного Доминирования США: экономического, технологического, информачионного, научного, идеологического, брендов и трендов.

Особенно эффектны в медиатексте регулятивные структуры, которые привлекают внимание адресата и отражают метафорический стиль мышления журналиста:

- сочетание хиазма и графических средств регулятивности: Идеология помогла Силе - Сила подтвердила идеологию;

- использование метафор в сочетании с графическими средствами регулятивности: Цивилизачия остается - просто уже не задает дискурс миру, она сама в чем-то становится ПОДЧИНЕННОЙ; В этом смысле у США была Историческая Фора; Их Система много раз показывала способность $\kappa$ Перезагрузке, а кризисы могут как раз «взбадривать»; Тень Китая ложится на США, на Заnad;

- применение метафор в сочетании с анафорами и антитезой: Eвропа весь $X I X-$ начало XX века мучительно, зигзагами догоняла идеологию Франиузской Революиии - изживала сословное общество. А в США его не было изначально... Европа истомала себя войнами - в США после Гражданской войны их не было, а 1 и $2 \mathrm{MB}$ их только обогатили и материально, и, что особенно важно, морально: они вступили в Западную Европу как Спасители...

Таким образом, в статье Л. Радзиховского «Величие Америки» регулятивность как системное качество медиатекста получает многоаспектное проявление, отражая идиостиль автора, его метафорический когнитивный потенциал, высокую речевую культуру, особенности мировосприятия, умение организовать диалог с массовым адресатом, управляя его познавательной деятельностью на основе стратегии последовательного приобщения адресата к позиции автора.

Чтобы показать многообразие средств репрезентации категории диалогичности газетнопублицистического текста на материале медиадискурса Леонида Радзиховского, обратимся к другой статье автора - «Русский след» (Радзиховский, 2020б). Поверхностный смысл этой статьи в «Российской газете» можно интерпретировать как размышления о современной ситуации в США в связи с обострением расовой проблемы. Глубинный смысл данного медиатекста - обусловленная исторически общность некоторых социальных табу в России XIX в. и США. В отличие от ранее рассмотренной статьи, автор использует здесь регулятивную лексическую макроструктуру имплицитного сравнительносопоставительного типа, неявно актуализируя свою интенцию, постепенно приобщая адресата к своей точке зрения.

Это достигается благодаря такому способу регулятивности, как конвергенция, при которой весь комплекс использованных автором средств ориентирован на одну цель. Неслучайно доминантой регулятивности в этом медиатексте является сравнение, например: Морально-этические табу необходимы в общественном сознании, как, скажем, система аксиом в математической теории; массовая крестьянофилия, похожая на современную политкорректность. При этом сравнение как регулятивная структура часто используется автором в сочетании с другими средствами и структурами:

- сравнение в сочетании с графическими средствами: На рубеже $X I X-X X$ веков Англия тоже выступала Мировым Моральным Лидером (хотя в меньшей мере, чем США на рубеже $X X-X X I)$;

- сравнение в сочетании с антитезой (противопоставлением ситуаций в России и США): Бунину такое прощали, но писатель чином поменьше за такую ересь был бы 
сожжен на костре - как сегодня профессор Гарварда за невосторженный образ мысли в отношении негров;

- сравнение в сочетании с цифровыми регулятивными средствами: Рабов в США перед освобождением было 4 млн. из 31 млн. населения, крепостных в России 23 млн. из 80 млн. населения (а в «самой России» без окраин - из 65 млн.);

- сравнение России и США, усиленное приемом повтора: Рабство в США отменили в 1862-1865 г2., крепостное право в России - в 1861-м (использовано 2 раза); В России перед и особенно после падения крепостного права была массовая крестьянофилия, похожая на современную политкорректность (употреблено 2 раза).

Как и в ранее рассмотренной статье, автор обращается к характерным для его стиля регулятивным средствам, расширяя их спектр и употребляя:

- графические средства - выделение ключевых слов прописными буквами: $С В О И$ корпоративно-классовые интересы, иногда используя их в сочетании с написанием отдельных слов со строчной буквой: $\mathrm{Ho} \kappa \mathrm{Ha}$ роду апеллировала и Монархия! Простое, безусловное ощущение СВОЕЙ легитимности размывалось;

- графические средства в сочетании с градацией: Так шумно спорили друг с другом - от имени и во имя Великого Немого Народа - «народовольщы» сверху и снизу, справа и слева;

- графические средства, усиленные иронией: Раз у интеллигенции есть Мессианский комплекс - то нужен «спасаемый ею» и Избранный Народ;

- окказионализмы: СМИ-задворки; табу-история; крестьянофилия;

- метафоры в сочетании с окказионализмами и иронией: новейшая гимнастика в США - вставать на "рукопожатные колени» перед чернокожими; Еще важнее, что негры были отделены расовым рвом от американского общества;

- метафорические эвфемизмы, образные перифразы: Русский След в Америке (трактуется автором «как жесткая система социальных табу, характерная для России XIX века и США»); моральные колени (определяется как «табу на любую критику расовых и сексменьшинств»);

- прецедентные тексты: охота на русских ведьм; Священные коровы; разбуженный Народ;

- аллюзии с романом Ф.М. Достоевского «Преступление и наказание»: «и мне это, сударь, в наслаждение», как говорил про такую позу Мармеладов (иронически); с романом «Двенадцать стульев» И. Ильфа и Е. Петрова: «не корысти ради - а токмо волею пославшей мя жены», то есть во имя Hарода.

Из регулятивных структур в анализируемой статье автором использованы:

- риторический вопрос в сочетании с индивидуально-авторским новообразованием: Интересно, будет ли сделан анализ политкорректного двоемыслия и связанных с ним неврозов?;

- градация: способен - жечь имения, «грабить награбленное» и идти за террористами (эсеры);

- текстовая парадигма номинатов с градацией: крестьяне, «глубинный народ», «меньшой брат», «серые зипуныл» превратились в Священных коров.

Таким образом, в статье «Русский след» Л. Радзиховского категория диалогичности реализуется с ориентацией на вдумчивого и культурного читателя с достаточно большим информационным тезаурусом, включая знание истории России, способного воспринимать не только поверхностный смысл медиатекста, но и глубинный, судя по многообразию и особенностям использованных автором средств и способов регулятивности. Индивидуальноавторские особенности проявляются в характерном для журналиста метафорическом когнитивном стиле, ярко выраженном личностном начале, масштабе и глубине информационного тезауруса, принадлежности к носителям элитарной речевой культуры.

В целом проведенный анализ регулятивности медиатекстов позволяет судить о том, что средства репрезентации категории диалогичности в рассмотренных статьях несколько отличаются от типовых средств выражения данной текстовой категории в газетнопублицистических текстах, отмеченных исследователями. Например, риторические и 


\section{ТЕОРЕТИЧЕСКИЕ ПРОБЛЕМЫ ИССЛЕДОВАНИЯ ТЕКСТОВ}

восклицательные предложения, тропы, оценочные, стилистически окрашенные лексемы, лексемы, передающие эмоциональное состояние, отнесенные Л.Р. Дускаевой к периферийным средствам диалогичности газетных текстов [Дускаева, 2003, с. 136], в рассмотренных нами медиатекстах являются ключевыми, особенно важными в диалоге с адресатом.

\section{Заключение}

Коммуникативно-деятельностный подход к медиатексту, основанный на методике анализа регулятивности как системного качества текста, позволил выявить различные средства и способы организации диалога с массовым адресатом, характерные как для публицистического текста вообще, так и для стилистической манеры конкретного автора, «стоящего» за текстом.

Средства репрезентации категории диалогичности в медиатексте отличаются от средств выражения диалогичности в других типах текстов [Болотнова, 2017а], при этом языковая личность журналиста, коммуникативнокогнитивные особенности его идиостиля, ценностная картина мира становятся важными факторами, существенно влияющими на диалог с адресатом.

Категория диалогичности медиатекста в его газетно-публицистической разновидности характеризуется повышенной экспрессией и оценочностью, которые реализуются поразному [Болотнова, 2017б]. Регулятивность медиатекстов и их воздействие на коллективного адресата могут существенно отличаться в зависимости от личности автора, его информационного поля, темы, жанра и других факторов.

\section{СПИСОК ЛИТЕРАТУРЫ}

Арутюнова Н. Д., 1990. Дискурс // Лингвистический энциклопедический словарь. М. : Сов. энцикл. С. 136-137.

Барт Р., 2001. Лингвистика текста // Текст: аспекты изучения : Поэтика. Прагматика. Семантика. M. : URSS. C. 168-175.

Бахтин М. М., 1997. Проблема текста в лингвистике, филологии и других гуманитарных науках : Опыт философского анализа // Русская сло- весность: от теории словесности к структуре текста : антология / под ред. проф. В. П. Нерознака. М. : Academia. С. 227-249.

Болотнов А. В., 2015. Текстовая деятельность как отражение коммуникативного и когнитивного стилей информационно-медийной языковой личности. Томск : Изд-во Том. ЦНТИ. 274 с.

Болотнова Н. С., 1998. О теории регулятивности художественного текста // Stylistyka. VII. S. 179-189.

Болотнова Н. С., 2008. Теория регулятивности текста в современном научном контексте // Семантика и прагматика слова в художественном и публицистическом дискурсах : материалы IX Bсерос. науч. семинара (25-26 апр. 2008 г.). Томск : Изд-во ЦНТИ. С. 151-160.

Болотнова Н. С., 2009. Коммуникативная стилистика текста : слов.-тезаурус. М. : Флинта. 384 с.

Болотнова Н. С., 2017а. Индивидуально-персонологические особенности публичной языковой личности как фактор воздействия в медиадискурсе // Вестник Томского государственного педагогического университета. № 11 (188). C. 53-60. DOI: 10.23951/1609-624X-2017-11-53-60.

Болотнова Н. С., 2017б. Изучение воздействия медиадискурса публичной языковой личности на коллективного адресата (по данным экспериментов) // Вестник Томского государственного педагогического университета. Вып. 7 (184). C. 32-40. DOI: 10.23951/1609-624X-2017-7-32-40.

Болотнова Н. С., 2018. Идиостиль журналиста // Медиалингвистика в терминах и понятиях : слов.справ. / под ред. Л. Р. Дускаевой. М. : Флинта. С. 201-204.

Болотнова Н. С., 2019. Методики смыслового и лингвопрагматического анализа медиатекста. М. : Флинта. 156 с

Гаспаров Б. М., 1996. Язык, память, образ. Лингвистика языкового существования. М. : Новое лит. обозрение. 352 с.

Дейк Т. ван, 1989. Язык. Познание. Коммуникация. М. : Прогресс. 312 c.

Дейк Т. А. ван, 2001. Вопросы прагматики текста // Текст: аспекты изучения : Поэтика. Прагматика. Семантика. M. : URSS. C. 90-167.

Демьянков В. 3., 1983. Понимание как интерпретирующая деятельность // Вопросы языкознания. № 6. С. 58-76.

Дускаева Л. Р., 2003. Категория диалогичности (функциональная семантико-стилистическая) // Стилистический словарь русского языка / под ред. М. Н. Кожиной. М. : Флинта. С. 130-139.

Ионова С. В., 2005. Аппроксимация содержания как основное свойство вторичных текстов // Вестник Волгоградского государственного университета. Серия 2, Языкознание. Вып. 4. C. 33-37. 
Ионова С. В., 2006. Аппроксимация содержания вторичных текстов. Волгоград : Изд-во ВолГУ. $380 \mathrm{c}$.

Казак М. Ю., 2014. Современные медиатексты: проблемы идентификации, делимитации типологии // Медиалингвистика. Вып. 1. С. 65-76.

Каменская О. Л., 1990. Текст и коммуникация. М. : Высш. шк. 152 c.

Карасик В. И., 2004. Языковой круг: личность, концепты, дискурс. М. : Гнозис. 390 с.

Кожина М. Н., 1986. О диалогичности письменной научной речи. Пермь : ПГУ. 91 с.

Коммуникативная стилистика текста: лексическая регулятивность в текстовой деятельности, 2011 / под ред. Н. С. Болотновой. Томск : Изд-во Том. гос. пед. ун-та. 492 с.

Сидоров Е. В., 1987. Проблемы речевой системности. М. : Наука. 140 с.

Солганик Г. Я., 2003. Публицистический стиль // Стилистический энциклопедический словарь / под ред. М. Н. Кожиной. М. : Флинта. С. 312-315.

Языковая личность и медиасреда : коммуникативнокогнитивные аспекты взаимодействия, 2017 / под ред. Н. С. Болотновой. Томск : Изд-во Том. ЦНТИ. $248 \mathrm{c}$.

\section{ИСТОЧНИКИ}

Радзиховский, 2020а - Радзиховский Л. Величие Америки // Российская газета - Федеральный выпуск. 2020. 2 нояб. (№248 (8302)). URL: https:// rg.ru/2020/11/02/radzihovskij-o-problemahssha-vechnyh-chempionov-ne-byvaet.html (дата обращения: 11.11.2020).

Радзиховский, $2020 б$ - Радзиховский Л. Русский след // Российская газета - Федеральный выпуск. 2020. 3 авг. (№ 170 (8224)). URL: https:// rg.ru/2020/08/03/radzihovskij-moralno-eticheskietabu-neobhodimy-v-obshchestvennomsoznanii.html (дата обращения: 11.11.2020).

\section{REFERENCES}

Arutjunova N.D., 1990. Diskurs [Discourse]. Lingvisticheskiy entsiklopedicheskiy slovar [Linguistic Encyclopedic Dictionary]. Moscow, Sovetskaya entsiklopediya Publ., pp. 136-137.

Bart R., 2001. Lingvistika teksta [Linguistic of the Text]. Tekst: aspekty izucheniya: Poetika. Pragmatika. Semantika [Text: Aspects of Study. Poetics. Pragmatics. Semantics]. Moscow, URSS Publ., pp. 168-175.

Bakhtin M.M., 1997. Problema teksta v lingvistike, filologii i drugikh gumanitarnykh naukakh: Opyt filosofskogo analiza [Text Problem in Linguistics, Philology and Other Humanities. Experience of PhilosophyAnalysis]. Neroznak V.P., ed. Russkaya slovesnost: ot teorii slovesnosti $k$ strukture teksta: antologiya [Russian Literature. From the Theory of Literature to the Structure of the Text. Anthology]. Moscow, Academia Publ., pp. 227-249.

Bolotnov A.V., 2015. Tekstovaya deyatelnost kak otrazhenie kommunikativnogo i kognitivnogo stiley informatsionno-mediynoy yazykovoy lichnosti [Textual Activity of Informational and Media Language Personality as a Reflection of Its Communicative and Cognitive Styles]. Tomsk, Izd-vo Tomskogo TsNTI. 274 p.

Bolotnova N.S., 1998. O teorii regulyativnosti khudozhestvennogo teksta [On the Theory of Regularity of a Literary Text]. Stylistyka, VII, s. 179-189.

Bolotnova N.S., 2008. Teoriya regulyativnosti teksta v sovremennom nauchnom kontekste [The Theory of Regulativity of a Text in a Present-Day Scientific Context]. Semantika i pragmatika slova $v$ khudozhestvennom i publitsisticheskom diskursakh: materialy IX Vseros. nauch. seminara (25-26 apr. 2008 g.) [Semantics and Pragmatics of a Word in Fiction and Publicistic Discourse. Proceedings of $9^{\text {th }}$ All-Russian Scientific Seminar (April 25-26, 2008)]. Tomsk, Izd-vo TsNTI, pp.151-160.

Bolotnova N.S., 2009. Kommunikativnajya stilistika teksta: slov.-tezaurus [Communicative Stylistics of Text. Thesaurus]. Moscow, Flinta Publ. 384 p.

Bolotnova N.S., 2017a. Individualnopersonologicheskie osobennosti publichnoy yazykovoy lichnosti kak faktor vozdeystviya $\mathrm{v}$ mediadiskurse [Individual and Personological Characteristics of a Public Linguistic Personality as a Factor of Influence in Media Discourse]. Vestnik Tomskogo gosudarstvennogo pedagogicheskogo universiteta [Tomsk State Pedagogical University Bulletin], no. 11 (188), pp. 53-60. DOI: 10.23951/1609-624X-2017-11-53-60.

Bolotnova N.S., 2017b. Izuchenie vozdeystviya mediadiskursa publichnoy yazykovoy lichnosti na kollektivnogo adresata (po dannym eksperimentov) [Study of the Impact of Media Discourse of a Public Language Personality on a Collective Addressee (According to Experiments)]. Vestnik Tomskogo gosudarstvennogo pedagogicheskogo universiteta [Tomsk State Pedagogical University Bulletin], iss. 7 (184), pp. 32-40. DOI: 10.23951/1609-624X-2017-7-32-40.

Bolotnova N.S., 2018. Idiostil zhurnalista [Jornalist's Idiostyle]. Duskaeva L.R., ed. Medialingvistika $v$ terminakh $i$ ponyatiyakh: slov.-sprav. [Medialinguistics in Terms and Concepts. 


\section{ТЕОРЕТИЧЕСКИЕ ПРОБЛЕМЫ ИССЛЕДОВАНИЯ ТЕКСТОВ}

Dictionary-Reference]. Moscow, Flinta Publ., pp. 201-204.

Bolotnova N.S., 2019. Metodiki smyslovogo $i$ lingvopragmaticheskogo analiza mediateksta [Methods of Semantic and Linguopragmatic Analysis of Media Text]. Moscow, Flinta Publ. $156 \mathrm{p}$.

Gasparov B.M., 1996. Yazyk, pamjat, obraz. Lingvistika yazykovogo sushchestvovaniya [Language, Memory, Image. Linguistics of Linguistic Existence]. Moscow, Novoe literaturnoe obozrenie Publ. 352 p.

Dejk T. van, 1989. Yazyk. Poznanie. Kommunikatsiya [Language. Cognition. Communication]. Moscow, Progress Publ. 312 p.

Dejk T.A. van, 2001. Voprosy pragmatiki teksta [Questions of Text Pragmatics]. Tekst: aspekty izuchenija: Poetika. Pragmatika. Semantika [Text: Aspects of Study: Poetics. Pragmatics. Semantics]. Moscow, URSS, pp. 90-167.

Demyankov V.Z., 1983. Ponimanie kak interpretiruyushchajya deyatelnost [Understanding as an Interpreting Activity]. Voprosy yazykoznaniya [Questions of Linguistics], no. 6, pp. 58-76.

Duskaeva L.R., 2003. Kategoriya dialogichnosti (funktsionalnaya semantiko-stilisticheskaya) [The category of dialogicality (functional semantic-stylistic)]. Duskaeva L.R., ed. Stilisticheskiy slovar russkogo yazyka [Stylistic dictionary of the Russian language]. Moscow, Flinta Publ., Nauka Publ., pp. 130-139.

Ionova S.V., 2005. Approksimatsiya soderzhaniya kak osnovnoe soderzhanie vtorichnykh tekstov [Approximation of Content as the Main Characteristic of Secondary Texts]. Vestnik Volgogradskogo gosudarstvennogo universiteta. Seriya 2. Yazykoznanie [Science Journal of Volgograd State University. Linguistics], iss. 4, pp. 33-37.

Ionova S.V., 2006. Approksimatsiya soderzhaniya vtorichnykh tekstov [Approximation of the Content of Secondary Texts]. Volgograd, Izd-vo VolGU. 380 p.

Kazak M.Yu., 2014. Sovremennye mediateksty: problemy identifikatsii, delimitatsi i tipologii [Modern Media Texts: Problems of Identification, Delimitation And Typology]. Medialingvistika [Media Linguistics], iss. 1, pp. 65-76.
Kamenskaya O.L., 1990. Tekst i kommunikatsiya [Text and Communication]. Moscow, Vysshaya shkola Publ. $152 \mathrm{p}$.

Karasik V.I., 2004. Yazykovoy krug: lichnost, kontsepty, diskurs [Language Circus: Personality, Concepts, Discourse]. Moscow, Gnozis Publ. $390 \mathrm{p}$.

Kozhina M.N., 1986. O dialogichnosti pismennoy nauchnoy rechi [On the Dialogic Nature of Written Scientific Speech]. Perm, PGU. 91 p.

Bolotnova N.S., ed., 2011. Kommunikativnayja stilistika teksta: leksicheskaya regulyativnost $v$ tekstovoy deyatelnosti [Communicative Stylistics of Text: Lexical Regulativity in Textual Activity]. Tomsk, Izd-vo Tomskogo gosudarstvennogo pedagogicheskogo universiteta. $492 \mathrm{p}$.

Sidorov E.V., 1987. Problemy rechevoy sistemnosti [Problems of Speech Consistency]. Moscow, Nauka Publ. 140 p.

Solganik G.Ya., 2003. Publitsisticheskiy stil [Piblicistic Style]. Kozhina M.N., ed. Stilisticheskiy enciklopedicheskiy slovar [Stylistic Encyclopedic Dictionary]. Moscow, Flinta Publ., pp. 312-315.

Bolotnova N.S., ed., 2017. Yazykovaya lichnost $i$ mediasreda: kommunikativno-kognitivnye aspekty vzaimodeystviya [Language Personality and Media Sphere: Communicative Cognitive Aspects of Collaboration]. Tomsk, Izd-vo Tomskogo TsNTI. 248 p.

\section{SOURCES}

Radzikhovsky L. Velichie Ameriki [Greatness of America]. Rossiyskaya gazeta - Federalnyy vypusk [Rossiyskaya Gazeta - Federal Issue], 2020, November 2, (no. 248 (8302)). URL: https:// rg.ru/2020/11/02/radzihovskij-o-problemahssha-vechnyh-chempionov-ne-byvaet.html (accessed 11 November 2020).

Radzikhovsky L. Russkiy sled [Russian Trace]. Rossiyskaya gazeta - Federalnyy vypusk [Rossiyskaya Gazeta - Federal Issue], 2020, August 3 (no. 170 (8224)). URL: https://rg.ru/ 2020/08/03/radzihovskij-moralno-eticheskietabu-neobhodimy-v-obshchestvennomsoznanii.html (accessed 11 November 2020). 
Н.С. Болотнова. Категория диалогичности медиатекста как отражение идиостиля автора

\section{Information About the Author}

Nina S. Bolotnova, Doctor of Sciences (Philology), Professor, Head of the Department of the Russian Language, Tomsk State Pedagogical University, Kievskaya St, 60, 634061 Tomsk, Russia, nsb@tspu.edu.ru, https://orcid.org/0000-0003-4655-5194

\section{Информация об авторе}

Нина Сергеевна Болотнова, доктор филологических наук, профессор, заведующая кафедрой русского языка, Томский государственный педагогический университет, ул. Киевская, 60, 634061 г. Томск, Россия, nsb@tspu.edu.ru, https://orcid.org/0000-0003-4655-5194 